\title{
Transient Congenital Hypothyroidism Alters Gene Expression of Glucose Transporters and Impairs Glucose Sensing Apparatus in Young and Aged Offspring Rats
}

\author{
Hanieh Gholami ${ }^{a}$ Sajad Jeddi ${ }^{b} \quad$ Azita Zadeh-Vakilic Khadije Farrokhfall ${ }^{d}$ \\ Fatemeh Rouhollahe Maryam Zarkesh ${ }^{c}$ Mahboubeh Ghanbarib \\ Asghar Ghasemib
}

\begin{abstract}
aDepartment of Genetics, Tehran Medical Sciences Branch, Islamic Azad University, Tehran, bEndocrine Physiology Research Center, Research Institute for Endocrine Sciences, Shahid Beheshti University of Medical Sciences, Tehran, 'Cellular and Molecular Endocrine Research Center, Research Institute for Endocrine Sciences, Shahid Beheshti University of Medical Sciences, Tehran, ${ }^{\mathrm{d} A}$ Atherosclerosis and Coronary Artery Research Center, Department of Physiology, Faculty of Medicine, Birjand University of Medical Sciences, Birjand, eDepartment of Cellular and Molecular Biology, Tehran Medical Sciences Branch, Islamic Azad University, Tehran, Iran
\end{abstract}

\section{Key Words}

Transient congenital hypothyroidism - Carbohydrate metabolism - Insulin • Rat • Glucose transporter

\begin{abstract}
Background/Aims: Transient congenital hypothyroidism (TCH) could disturb carbohydrate metabolism in adulthood. Aging is associated with increased risk of type 2 diabetes. This study aims to address effects of TCH on mRNA expressions of glucose transporters (GLUTs) and glucokinase (GCK) in islets and insulin target tissues of aged offspring rats. Methods: The TCH group received water containing 0.025\% 6-propyl-2-thiouracil during gestation. Offspring from control and TCH groups ( $n=6$ in each group) were followed until month 19. Gene expressions of GLUTs and GcK were measured at months 3 and 19. Results: Compared to controls, aged TCH rats had higher GLUT4 expression in heart (4.88 fold) and soleus (6.91 fold), while expression was lower in epididymal fat (12\%). In TCH rats, GLUT2 and GcK expressions in islets were lower in young (12\% and $10 \%$, respectively) and higher in aged (10.85 and 8.42 fold, respectively) rats. In addition, liver GLUT2 and GcK expressions were higher in young (13.11 and 21.15 fold, respectively) and lower in aged rats (44\% and 5\%, respectively). Conclusion: Thyroid hormone deficiency during fetal period impaired glucose sensing apparatus and changed glucose transporter expression in insulin-sensitive tissues of aged offspring rats. These changes may contribute to impaired carbohydrate metabolism.




\section{Cellular Physiology Cell Physiol Biochem 2017;43:2338-2352 \\ \begin{tabular}{ll|l} 
and Biochemistry & $\begin{array}{l}\text { DOI: 10.1159/000484386 } \\
\text { Published online: October 27, } 2017\end{array}$ & $\begin{array}{l}\text { C } 2017 \text { The Author(s). Published by S. Karger AG, Basel } \\
\text { www.karger.com/cpb }\end{array}$ \\
\hline
\end{tabular}}

\section{Introduction}

Intrauterine growth retardation (IUGR) is associated with increased risk of metabolic disorders, in particular type 2 diabetes in later life [1,2]. Thyroid hormones play an important role during fetal development [3-5]. Congenital hypothyroidism (CH) is a state of thyroid hormone insufficiency that starts in utero and is present at birth or postnatally $[3,6,7]$; $\mathrm{CH}$ in classified into permanent and transient forms $[6,8]$. Transient $\mathrm{CH}(\mathrm{TCH})$ is a temporary deficiency of thyroid hormones at birth that then recovers to normal state $[6,7]$. Maternal intake of anti-thyroid drugs is one of the cause of TCH [6]. The incidence of TCH is very low in iodine-sufficient areas such as the United States (1 in 50000) or very high in the iodine-deficient areas such as Europe (1 in 100) [6] and Africa (1 in 10) [9]. Hypothyroidism during pregnancy can cause glucose intolerance during adulthood $[10,11]$ that is a result of disturbed intrauterine conditions [12,13].

Aging is associated with glucose intolerance and type 2 diabetes [14-16]. Insulin resistance [17-19], impaired $\beta$-cell function $[15,17,18,20]$, accumulation of lipid in muscle and liver [17], impaired insulin secretion $[15,17]$ and, in particular, altered expression of glucose transporters (GLUTs) [21, 22], contribute to age-associated type 2 diabetes. In addition, data from the Helsinki Birth Cohort Study show that the risk of type 2 diabetes is higher in aged subjects who were small at birth [23, 24].

The mechanisms underlying disturbed carbohydrate metabolism in aged rats with thyroid hormone deficiency during fetal life have not yet been elucidated. Data about effects of TCH on GLUTs expression in insulin-sensitive tissues are conflicting, with no change, decreased, or increased expressions being reported, as well as tissue-specific effects [2527]. It has also been reported that decrease in GLUT2 and glucokinase (GcK) in liver and pancreatic islets are involved in glucose disturbance observed in adult hypothyroidism [28, 29]. Data on the effects of aging on expression of GLUTs and GcK are controversial [21, 3033] and altered expression of GLUTs in insulin-sensitive tissues and defects in the glucose sensing apparatus may be involved in glucose intolerance observed with aging [21,34].

Both GLUT1 and GLUT4 have been found in insulin-sensitive tissues (heart muscle, skeletal muscle, and adipose tissue) [21, 25, 35]. In addition, GcK and GLUT2 have been found in pancreatic islets and liver [15,34]. To the best of our knowledge, there is no study to date addressing the effects of thyroid hormone deficiency during fetal life on carbohydrate metabolism and glucose sensing apparatus in aged offspring rats. The aim of this study was therefore to determine whether TCH affects carbohydrate metabolism and expression of GLUTs and GcK in aged offspring rats.

\section{Materials and Methods}

\section{Animals}

In this study, 3-month and 19-month-old male Wistar rats, used as young and aged rats, respectively, were obtained from animal house of the Research Institute for Endocrine Sciences (RIES) of Shahid Beheshti University of Medical Sciences, Tehran, Iran. They were housed in a controlled room with temperature of $23 \pm 3^{\circ} \mathrm{C}$, and an inverse $12: 12 \mathrm{~h}$ light/dark cycle. Rats had free access to standard rat chow (Pars Animal Feed Co., Tehran, Iran) and tap water during the study. This study was approved by the local ethics committee of the RIES (Ethic code: 11ECRIES94/02/15); all procedures were performed in accordance with the National Institutes of Health guide for the care and use of Laboratory Animals [36].

\section{Sample size calculation}

In this study, we used resource equation method in combination with sequential stopping rule for calculation of sample size $[37,38]$. According to the resource equation method: $E=$ total number of animals - total number of groups; $E=10-20$ means that the sample size is appropriate and if $20<E<10$ then the sample size should be increased or decreased, respectively. Sequential stopping rule is a highly efficient and 


\section{Cellular Physiology Cell Physiol Biochem 2017;43:2338-2352

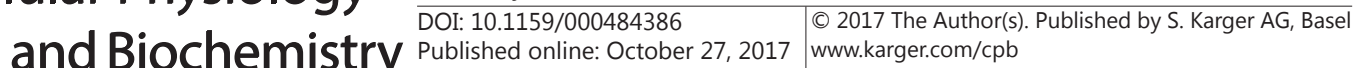

an excellent choice for decreasing both cost and number of animals. According to sequential stopping rule, after determining initial sample size (using resource equation method), statistical analyses are run and if $0.30<\mathrm{p}$ values $<0.05$, there is no need for further experiments otherwise $\mathrm{n} /$ group should be increased until access to the condition.

Experimental protocols and induction of transient congenital hypothyroidism

Virgin female Wistar rats $(n=10$, body weight $190 \pm 10)$, in the proestrus phase, determined by vaginal smears, were housed overnight with male rats $(n=10$, body weight $250 \pm 20)$ of the same age ( 1 female with 1 male) in polypropylene cages. Successful mating was confirmed by the presence of sperm in the vaginal smears on the first day after mating; this day was considered as day 1 of pregnancy.

Pregnant female rats were housed in individual cages and then randomly divided into the $0.025 \%$ PTU (6-propyl-2-thiouracil)-consuming during pregnancy, and the control mother groups. The PTU-consuming mothers received PTU in drinking water during pregnancy (initiated at day 1 of pregnancy and discontinued at the time of delivery), while the control mothers received tap water only. After weaning (day 28 postnatal), the male offspring of the control and TCH group rats were housed in groups of two rats per cage, with free access to food and water.

Body weight was measured weekly from the first day of birth until the end of month 3, using A\&D scale, EK-300i, Japan; sensitivity $0.01 \mathrm{~g}$; and monthly, from the end of month 3 until the end of the experiment (month 19) using a Tefal scale, France; sensitivity $1 \mathrm{~g}$.

Blood samples were taken from both mothers (after delivery) and their male offspring (after 1416 hrs. fasting) at months $3,6,9,12$, and 19 for serum glucose, insulin, total triiodothyronine ( $\mathrm{TT}_{3}$ ), total thyroxine $\left(\mathrm{TT}_{4}\right.$ ), and thyroid stimulating hormone (TSH) measurements. In separate groups of neonates, blood samples were drawn for glucose and hormone measurements. GTT (glucose tolerance test) and gene expression studies were performed at 3 and 19 months. Blood sampling was drawn from the tail, except at months 3 and 19, when rats were sacrificed and blood was taken from heart.

\section{Biochemical measurements}

Twenty minutes after the blood was drawn, blood samples were centrifuged at $3000 \mathrm{rpm}$ for $10 \mathrm{~min}$ at $4^{\circ} \mathrm{C}$, and the sera were stored at $-80^{\circ} \mathrm{C}$ until time of assay; $\mathrm{TT}_{3}, \mathrm{TT}_{4}$, and $\mathrm{TSH}$ were measured using ELISA kits (Pishtaz Teb Zaman Co., Iran for $\mathrm{TT}_{3}$ and $\mathrm{TT}_{4}$; Zellbio Co., Germany for rat TSH). Since the structures of the thyroid hormones are not species specific, human kits could be used for measurement of $\mathrm{TT}_{3}$ and $\mathrm{TT}_{4}$ in rats [39-41]. Intra-assay coefficients of variation were $3.5 \%$ for $\mathrm{TT}_{3}, 5.1 \%$ for $\mathrm{TT}_{4}$ and $3.3 \%$ for TSH. Serum glucose was measured by the glucose oxidase method using a commercial kit (Pars Azmoon Co., Tehran, Iran); intra- and inter-assay coefficients of variation were 2.9 and $5.4 \%$, respectively. Serum insulin was measured with a rat-specific ELISA kit (Mercodia, Uppsala, Sweden); intra- and inter-assay coefficients of variation were $2.9 \%$ and $4.4 \%$, respectively.

\section{Glucose tolerance test}

IPGTT (intraperitoineal glucose tolerance test) was performed at the end of 3 and 19 months after 14$16 \mathrm{hrs}$. of fasting. In brief, rats were anaesthetized by an IP injection of pentobarbital sodium (60 mg/ $\mathrm{kg})$, a blood sample was obtained from the tail and glucose $(1 \mathrm{~g} / \mathrm{kg}$ body weight of $50 \%$ glucose solution) was then injected followed by blood sampling at 10, 20, 30, 60, and 120 min after the glucose injection; sera were separated and used for glucose measurement.

\section{Homeostasis model assessment}

Homeostasis model assessment (HOMA) was calculated as HOMA1 of insulin resistance (HOMA1-IR = fasting insulin $(\mathrm{lU} / \mathrm{mL}) \times$ fasting glucose $(\mathrm{mmol} / \mathrm{L})] / 22.5 ;$ HOMA1- of insulin sensitivity $($ HOMA1-S\%) = 1/HOMA1-IR × 100; and HOMA1 of ß-cell function (HOMA1-B\%) $=[20 \times$ fasting insulin $(\mathrm{lU} / \mathrm{mL})] /[$ fasting glucose (mmol/L)-3.5]. HOMA2-IR, HOMA2-S and HOMA2-B were calculated using the HOMA calculator, available at: http://www.dtu.ox.ac.uk/homacalculator [42].

\section{Isolation of pancreatic islets}

For pancreatic islet isolation a slightly modified Lacy method [43] was used [2]. In brief, the rats were anaesthetized using a pentobarbital sodium $(60 \mathrm{mg} / \mathrm{kg}$ ) IP injection. The pancreas was inflated with 


\section{Cellular Physiology Cell Physiol Biochem 2017;43:2338-2352

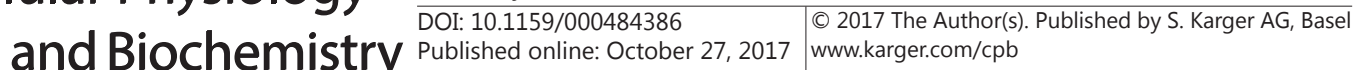

an injection of $10 \mathrm{~mL}$ ice-cold Hanks' balanced salt solution (HBSS) containing collagenase P $(0.5 \mathrm{mg} /$ $\mathrm{mL}$ ) administered through the bile duct; the inflated pancreas was removed, minced with scissors, and transferred to a sterile $50 \mathrm{ml}$ falcon tube, was then digested in a $37^{\circ} \mathrm{C}$ water bath $(15 \mathrm{~min})$. The digestion was terminated by the addition of ice-cold HBSS $(30 \mathrm{~mL})$, and the tube was then shaken (1 min). After three washings with cold HBSS, the suspension was filtered through a $500 \mu \mathrm{m}$ plastic mesh to discard any undigested tissue particles. Islets were handpicked under a stereomicroscope (Kyowa Optical, SDZ-TR-PL model, Japan), and were frozen in liquid nitrogen and stored at $-80{ }^{\circ} \mathrm{C}$ until further use.

\section{Real-time quantitative reverse transcription polymerase chain reaction (qRT-PCR)}

After anesthesia, the left ventricle of heart muscle, the soleus muscle, the epididymal adipose tissue, the liver, and the pancreatic islets were immediately removed and frozen in liquid nitrogen, prior to storage at $-80^{\circ} \mathrm{C}$.

Total RNA was extracted from homogenized tissues using the RNX-Plus solution kit (Cinagen Co., Tehran, Iran); the extraction was performed according to the kit manufacturer's instructions. The quantity and the purity of RNA samples were measured with a nanodrop spectrophotometer (NanoDrop-1000, Thermo Scientific, USA).

cDNA synthesis was done using Thermo Scientific RevertAid Reverse Transcriptase in accordance with manufacturer instructions. In brief, after DNase treatment, $3 \mu \mathrm{g}$ of total RNA was reversed to cDNA using M-MuLV RevertAid Reverse Rranscriptase $(1 \mu \mathrm{L}$ of $200 \mathrm{U} / \mu \mathrm{L})$, random hexamer primers $(1 \mu \mathrm{l}$ of $100 \mu \mathrm{M})$, dNTPS $(2 \mu \mathrm{L}$ of $10 \mathrm{mM})$, and RiboLock RNase-inhibitor $(0.5 \mu \mathrm{L}$ of $40 \mathrm{U} / \mu \mathrm{L})$, incubated for $10 \mathrm{~min}$ at $25^{\circ} \mathrm{C}$, followed by $60 \mathrm{~min}$ at $42^{\circ} \mathrm{C}$ in a total volume of $20 \mu \mathrm{L}$. The reaction was terminated by heating the reactions at $70^{\circ} \mathrm{C}$ for $10 \mathrm{~min}$.

Real time PCR. Primers were designed using the primer3 and GeneRunner; primer sequences are shown in Table 1. Amplifications were performed in a rotor gene 6000 real time PCR machine (Corbett, Life science, Sydney, Australia). All reactions were set up in $15 \mu \mathrm{L}$ volumes and contained $1 \mu \mathrm{L}$ cDNA, $0.5 \mu \mathrm{L}$ of each forward and reverse primer, 7.5 $\mu \mathrm{L}$ of SYBR Green PCR Master Mix 2X (ThermoFisher, USA), and 5.5 $\mu \mathrm{L}$ nuclease-free water. The following cycling profile was used for PCR reactions: initial denaturation $(10$ min at $95^{\circ} \mathrm{C}$ ) followed by 40 cycles with $45 \mathrm{~s}$ at $94{ }^{\circ} \mathrm{C}, 45 \mathrm{~s}$ at $58^{\circ} \mathrm{C}$ and $1 \mathrm{~min}$ at $72{ }^{\circ} \mathrm{C}$; final extension for 5 min at $72^{\circ} \mathrm{C}$. All samples were run in duplicate and $\mathrm{H}_{2} \mathrm{O}$ replaced templates in negative control reactions. The specificity of the real-time PCR reactions was verified by generation of a melting curve analysis. Target genes were normalized with reference genes [i.e. ß-actin for heart muscle and epididymal adipose tissue, as well as glyceraldehyde-3-phosphate dehydrogenase (GAPDH) for the soleus muscle, the pancreatic islets, and the liver]. The relative mRNA level for each target gene was calculated by the $2^{-\Delta \Delta C}{ }_{t}$ method [44], where $\Delta \mathrm{C}_{\mathrm{t}}$ (cycle threshold) $=\mathrm{C}_{\mathrm{t}}$ of target gene $-\mathrm{C}_{\mathrm{t}}$ of reference gene and $\Delta \Delta \mathrm{C}_{\mathrm{t}}=\Delta \mathrm{C}_{\mathrm{t}}$ of the target gene in the TCH group $-\Delta \mathrm{C}_{\mathrm{t}}$ of the target gene in the control group.

\section{Statistical analysis}

Results are expressed as mean \pm SEM. Statistical analyses were performed using SPSS (version 20) and GraphPad Prism (Version 6) softwares; the Shapiro-Wilk test was used to check the normality of the data and parametric or non-parametric tests were then used for the analysis of data with normal and non-normal distribution, respectively [45]. A two-way mixed (between-within) repeated measured ANOVA test, was used for comparing $\mathrm{TT}_{3}, \mathrm{TT}_{4}$, $\mathrm{TSH}$, glucose, insulin, and body weight between the two groups; comparison between each time point was done by independent sample t-test. The MannWhitney U test was used for comparing fold change in $\mathrm{mRNA}$ expression between groups. Two-sided $\mathrm{p}$ values $<0.05$ were considered statistically significant.

Table 1. Primers used for real time PCR analysis

\begin{tabular}{|c|c|c|c|}
\hline Primer name & $\begin{array}{l}\text { Gene bank } \\
\text { Accession No. }\end{array}$ & Primer sequence $\left(5^{\prime} \rightarrow 3^{\prime}\right)$ & $\begin{array}{l}\text { Product length } \\
\text { (bp) }\end{array}$ \\
\hline GLUT1 & NM 138827.1 & $\begin{array}{l}\text { Forward: CCATGTATGTGAGGGAGGTGT } \\
\text { Reverse: AGTCTAAGCCGAACACCTG }\end{array}$ & 111 \\
\hline GLUT2 & NM 012879.2 & $\begin{array}{l}\text { Forward: GCAACATGTCAGAAGAGAAGATCA } \\
\text { Reverse: AGGAGCATTGATCACACCGA }\end{array}$ & 107 \\
\hline GLUT4 & NM 012751.1 & $\begin{array}{l}\text { Forward: CGCACCACAGAAAGTGATTG } \\
\text { Reverse: GGTAGTGAGTGTGCCTTGTG }\end{array}$ & 100 \\
\hline GcK & NM 001270849.1 & $\begin{array}{l}\text { Forward: GGTCAGCAGCTGTACGAGAAG } \\
\text { Reverse: CCGTGTAACAGAAGGTTCTCG }\end{array}$ & 101 \\
\hline B-actin & NM 031144.3 & $\begin{array}{l}\text { Forward: GCGTCCACCTGCTAGTACAAC } \\
\text { Reverse: CGACGACTAGCTCAGCGATA }\end{array}$ & 100 \\
\hline GAPDH & NM 017008.4 & $\begin{array}{l}\text { Forward: TGCCGCCTGGAGAAACCTGC } \\
\text { Reverse: TGAGAGCAATGCCAGCCCCA }\end{array}$ & 172 \\
\hline
\end{tabular}


Fig. 1. Serum $\mathrm{TT}_{3}, \mathrm{TT}_{4}$, and $\mathrm{TSH}$ concentrations in control and transient congenital hypothyroid rats during study. (A) Serum $\mathrm{TT}_{3}$, (B) $\mathrm{TT}_{4}$, and (C) $\mathrm{TSH}$ concentrations in control and transient congenital hypothyroid rats. Values are mean \pm SEM; ( $\mathrm{n}=6$ rats/group). Statistical analysis was performed using two-way mixed repeated measured ANOVA test, and independent sample t-test for comparison between each time point, $\mathrm{P}<0.05$. $\mathrm{TT}_{3}$, total triiodothyronine; $\mathrm{TT}_{4}$, total thyroxine; $\mathrm{TSH}$, thyroid stimulating hormone; $\mathrm{C}$, control; $\mathrm{TCH}$, transient congenital hypothyroidism.

\section{Results}

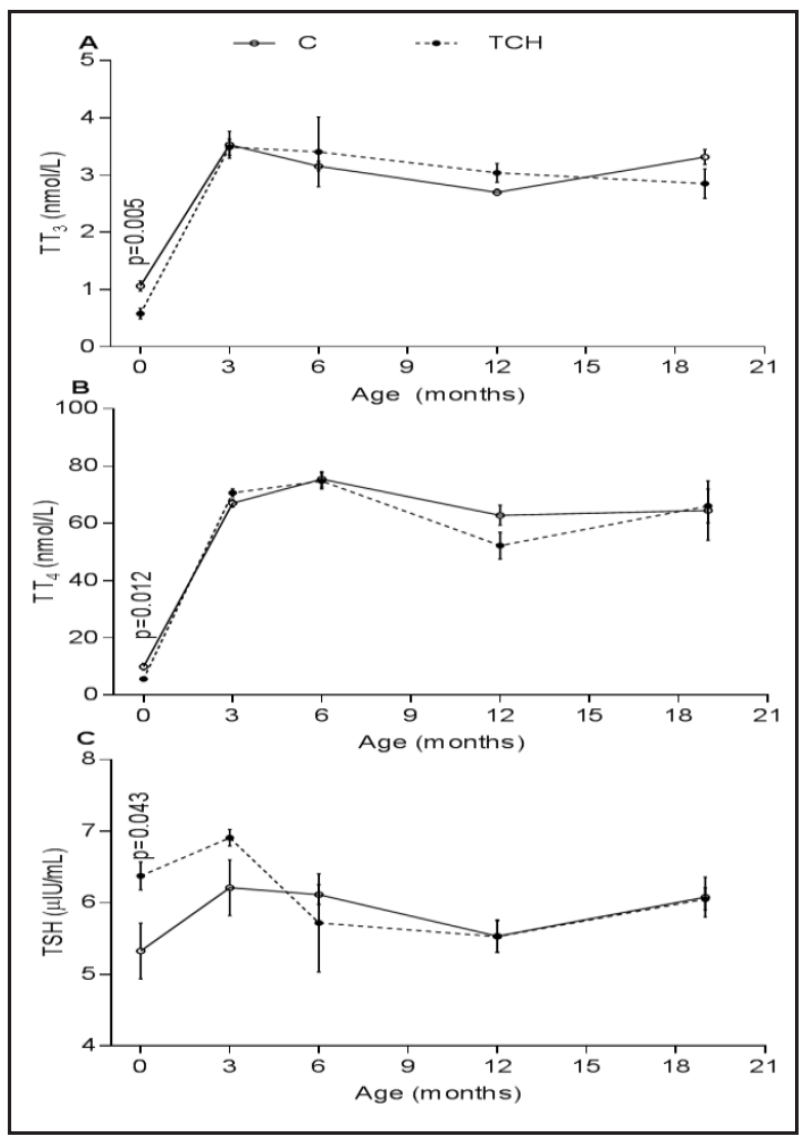

Serum concentrations of thyroid hormones and TSH

As shown in Fig. 1 (A-C), at the time of delivery, serum $\mathrm{TT}_{3}$ and $\mathrm{TT}_{4}$ in offspring were significantly lower than in controls, whereas serum TSH levels in offspring were significantly higher than in controls. Serum $\mathrm{TT}_{3}, \mathrm{TT}_{4}$, and TSH concentrations of TCH rats (at months 3, 6, 12,19 ) were not statistically different when compared with controls.

\section{Body weight}

Compared with controls, TCH rats had significantly lower body weight at birth $[4.17 \pm$ 0.12 vs. $6.37 \pm 0.11 \mathrm{~g}, \mathrm{p}<0.001$ ); a difference observed between the two groups until week 12 (Fig. 2A); after week 12, no significant difference between the TCH and the control group was noticed (Fig. 2B).

\section{Serum glucose and insulin concentrations}

Compared with controls, serum glucose concentrations were significantly higher in TCH rats throughout the study (Fig. 3A); conversely, serum insulin was significantly lower in TCH rats, except at month 9 (Fig. 3B). In addition, the area under the curve (AUC) shows that in $\mathrm{TCH}$ rats the serum glucose and insulin concentrations were significantly higher and lower than in controls, respectively.

\section{Glucose tolerance test}

The results of IPGTT at the end of months 3 and 19 show that fasting serum glucose was significantly higher in TCH rats than controls, i.e $4.45 \pm 0.35$ vs. $6.81 \pm 0.68 \mathrm{mmol} / \mathrm{L}$, $\mathrm{p}=0.010$ for month 3 and $6.04 \pm 0.53$ vs. $8.19 \pm 0.32 \mathrm{mmol} / \mathrm{L}, \mathrm{p}=0.007$ for month 19 . After the glucose injection, the increase in serum glucose concentration was higher in TCH rats than in controls (Figs. 4A and 4B). In addition, the AUC shows that serum glucose concentrations 




Fig. 2. Body weights in control and transient congenital hypothyroid rats. (A) Body weights in control and transient congenital hypothyroid rats from birth until week 13. (B) Body weights in control and transient congenital hypothyroid rats from month 4 until month 19. Values are mean \pm SEM ( $n=8 /$ group). Statistical analysis was performed using two-way mixed repeated measured ANOVA test, and independent sample t-test for comparison between each time point, $\mathrm{P}<0.05$. Inbox shows the body weight at the time of delivery. $\mathrm{C}$, control; $\mathrm{TCH}$, transient congenital hypothyroidism.

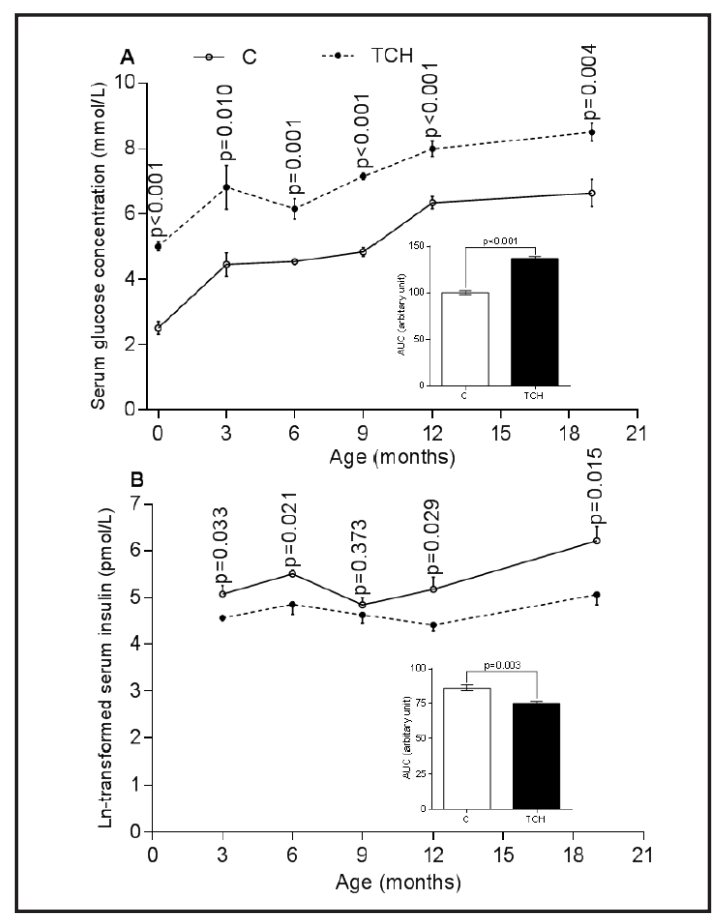

Fig. 3. Serum glucose and insulin concentrations in control and transient congenital hypothyroid rats during study. (A) Serum glucose and (B) insulin concentrations in control and transient congenital hypothyroid rats. Values are mean \pm SEM; ( $n=6$ rats/ group). Statistical analysis was performed using two-way mixed repeated measured ANOVA test, and independent sample t-test for comparison between each time point, $\mathrm{P}<0.05$. Inbox shows the area under the curve (AUC). C, control; TCH, transient congenital hypothyroidism.

during the IPGTT in TCH rats were significantly higher than in controls, i.e. $973.5 \pm 55.2$ vs. $782.1 \pm 31.3, \mathrm{p}=0.013$ for month 3 and $1273.0 \pm 40.4$ vs. $1024.4 \pm 56.3 \mathrm{p}=0.005$ for month 19 (Figs. 4A and 4B).

\section{Insulin resistance/sensitivity indices}

As shown in Fig. 5 (A-F), when compared with controls, TCH rats had significantly lower HOMA-IR and HOMA-B and higher HOMA-S.

\section{GLUT1 and GLUT4 mRNA expressions}

As Fig. 6 shows, when compared with controls (considered as 1), the expression of GLUT1 mRNA in TCH rats was 67, 16, and 45 percent of control value at month 3, and 49, 23, and 37 percent at month 19 of control value for heart muscle, soleus muscle, and epididymal adipose tissue, respectively (Figs. 6A and 6B). Compared with controls, in TCH rats, GLUT4 mRNA expression was 3.37 and 4.44 fold of controls at month 3, and 4.88 and 6.91 fold of controls at month 19 for heart and soleus muscles, respectively. In addition, the GLUT4 mRNA expression was $21 \%$ of control value at month 3 , and $12 \%$ of control value at month 19 for the epididymal adipose tissue (Figs. 6C and 6D). Compared to young animals, the mRNA expressions of both GLUT1 and GLUT4 in all the tissues studied decreased with aging, in both control and TCH rats (Fig. 7, A-D). 


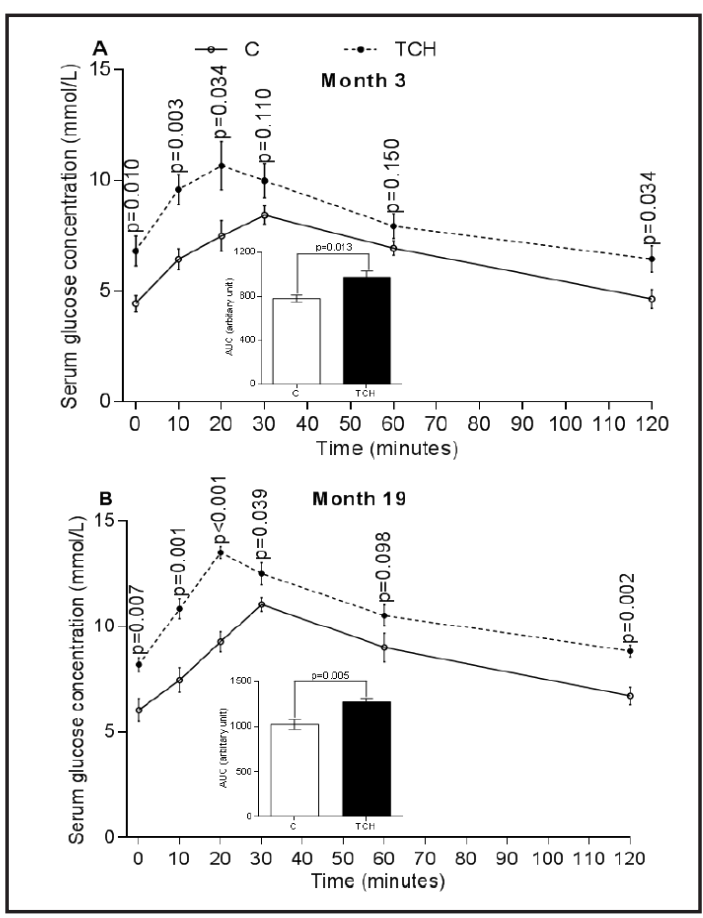

Fig. 4. Glucose tolerance test in control and transient congenital hypothyroid rats. (A) Glucose tolerance test in control and transient congenital hypothyroid rats at month 3. (B) Glucose tolerance test in control and transient congenital hypothyroid rats at month 19. Values are means \pm SEM ( $n=6 /$ group). Statistical analysis was performed using two-way mixed repeated measured ANOVA test, and independent sample t-test for comparison between each time point, $\mathrm{P}<0.05$. Inbox shows the area under the curve (AUC). C, control; TCH, transient congenital hypothyroidism.

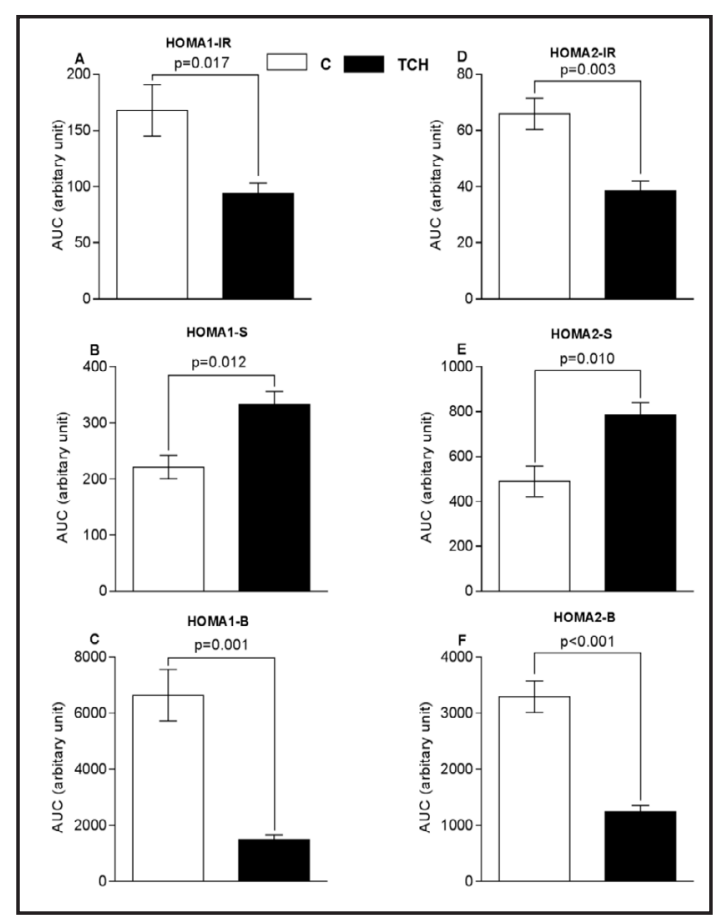

Fig. 5. Comparison of HOMA1 and HOMA2 indices between control and transient congenital hypothyroid rats. (A) AUC of HOMA1-IR, (B) AUC of HOMA1S, (C) AUC of HOMA1-B, (D) AUC of HOMA2-IR, (E) AUC of HOMA2-S, (F) AUC of HOMA2-B. Values are mean \pm SEM; ( $n=5 /$ group). Statistical analysis was performed using independent sample t-test, $\mathrm{P}<0.05$. AUC, area under the curve; HOMA, homeostasis model assessment; HOMA-IR, HOMA of insulin resistance; HOMA-S, HOMA of insulin sensitivity; HOMAB, HOMA of $ß$-cell function. C, control; TCH, transient congenital hypothyroidism.

\section{GLUT2 and GcK mRNA expressions}

As shown in Fig. 8, compared with controls, young TCH rats had higher level of GLUT2 (13.11 fold of controls) and GcK (21.15 fold of controls) expressions in the liver (Fig. 8A); lower level of GLUT2 (12\% of control value) and GcK (10\% of control value) expressions in pancreatic islets (Fig. 8C). The reverse pattern was observed in aged TCH rats in the liver (44\% for GLUT2 and 5\% for GcK of controls; Fig. 8B) and pancreatic islets (10.85 for GLUT2 and 8.42 for GcK fold of controls; Fig. 8D).

Compared to young animals, in aged control rats, the GLUT2 mRNA expression was higher ( 4.19 fold of controls) in the liver and lower in pancreatic islets ( $3 \%$ of control value), while mRNA expression of GcK was lower both in the liver and pancreatic islets (38\% and $3 \%$ of control value, respectively; Figs. 9A and 9C). Compared to young TCH rats, in aged ones, mRNA expressions of both GLUT2 and GcK were lower in the liver $111 \%$ and $3 \%$ of control value, respectively; Fig. 9B) and higher in pancreatic islets (3.86 and 5.35 fold of controls, respectively; Fig. 9D).

\section{Discussion}

Based on the results, this study shows, for the first time, that the thyroid hormone deficiency during fetal period impairs glucose sensing apparatus in pancreatic islets and 
Fig. 6. Effect of transient congenital hypothyroidism on mRNA expression of GLUT1 and GLUT4 in heart muscle, soleus muscle, and epididymal adipose tissue. (A) mRNA expression of GLUT1 in heart muscle, soleus muscle, and epididymal adipose tissue of transient congenital hypothyroid rats at month 3 . (B) mRNA expression of GLUT1 in heart muscle, soleus muscle, and epididymal adipose tissue of transient congenital hypothyroid rats at month 19 . (C) mRNA expression of GLUT4 in heart muscle, soleus muscle, and epididymal adipose tissue of transient congenital hypothyroid rats at month 3 . (D) mRNA expression of GLUT4 in heart
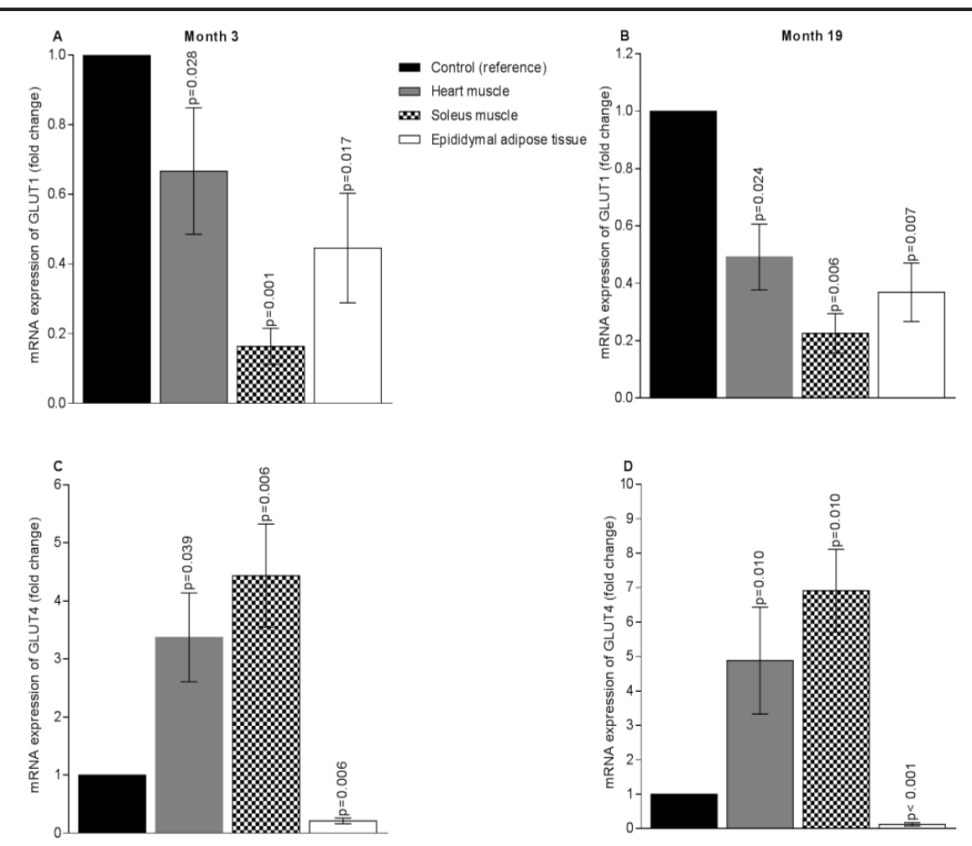
muscle, soleus muscle, and epididymal adipose tissue of transient congenital hypothyroid rats at month 19. mRNA expression in control group was considered 1. Values are mean \pm SEM; ( $n=6$ rats/group in duplicate). Statistical analysis was performed using the Mann-Whitney U test, $\mathrm{P}<0.05$. GLUT, glucose transporter; C, control; TCH, transient congenital hypothyroidism.

Fig. 7. Effect of aging on mRNA expression of GLUT1 and GLUT4. (A) mRNA expression of GLUT1 in heart muscle, soleus muscle, and epididymal adipose tissue in aged control rats compared to young control rats. (B) mRNA expression of GLUT1 in heart muscle, soleus muscle, and epididymal adipose tissue aged transient congenital hypothyroid rats compared to young transient congenital hypothyroid rats. (C) mRNA expression of GLUT4 in heart muscle, soleus muscle, and epididymal adipose tissue in aged control rats compared to young

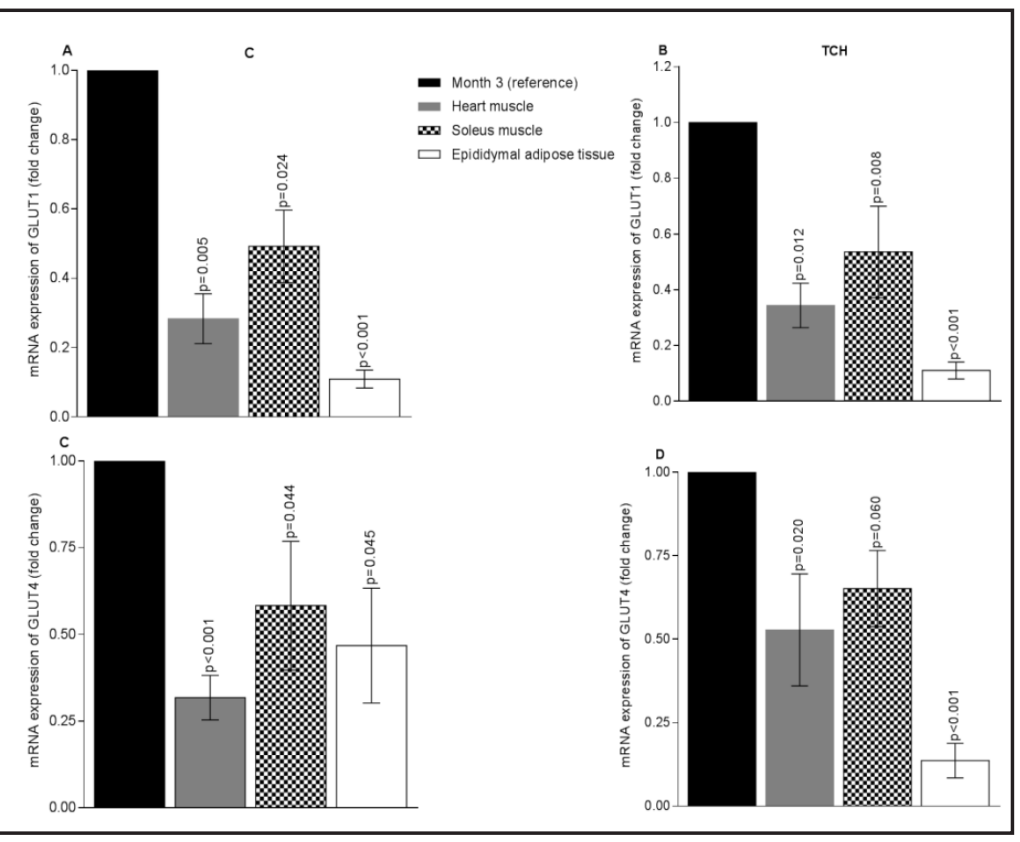
control rats. (D) mRNA expression of GLUT4 in heart muscle, soleus muscle, and epididymal adipose tissue aged transient congenital hypothyroid rats compared to young transient congenital hypothyroid rats. mRNA expression in young rats was considered 1 . Values are mea \pm SEM; ( $n=6$ rats/group in duplicate). Statistical analysis was performed using the Mann-Whitney U test, $\mathrm{P}<0.05$. GLUT, glucose transporter; C, control; TCH, transient congenital hypothyroidism.

changes expression of glucose transporters in insulin-sensitive tissues of both young and aged offspring rats. These changes might be the reason behind the impaired carbohydrate metabolism observed in animals born from hypothyroid mothers. 
Fig. 8. Effect of transient congenital hypothyroidism on mRNA expression of GLUT2 and GcK in pancreatic islets and liver tissue. (A) mRNA expression of GLUT2 and GcK in liver of transient congenital hypothyroid rats at month 3. (B) mRNA expression of GLUT2 and GcK in liver of transient congenital hypothyroid rats at month 19. (C) mRNA expression of GLUT2 and GcK in pancreatic islets of transient congenital hypothyroid rats at month 3 . mRNA expression of GLUT2 and $\mathrm{GcK}$ in pancreatic islets of transient congenital hypothyroid rats at month 19. mRNA expression in control group was considered 1. Values are mean \pm SEM; $(n=6$


rats/group in duplicate).Statistical analysis was performed using the Mann-Whitney U test, $P<0.05$. GLUT2, glucose transporter2; GcK, glucokinase; $\mathrm{C}$, control; $\mathrm{TCH}$, transient congenital hypothyroidism.

Fig. 9. Effect of aging on mRNA expression of GLUT2 and GcK. (A) GLUT2 and GcK mRNA expression in liver of aged control rats compared to young control rats. (B) GLUT2 and GcK mRNA expression in liver of aged transient congenital hypothyroid rats compared to young transient congenital hypothyroid rats. (C) GLUT2 and GcK mRNA expression in pancreatic islets of aged control rats young control rats. (D) GLUT2 and GcK mRNA expression in pancreatic islets of aged transient congenital hypothyroid rats compared to young transient congenital hypothyroid rats. mRNA expression in young rats was considered 1 . Values are

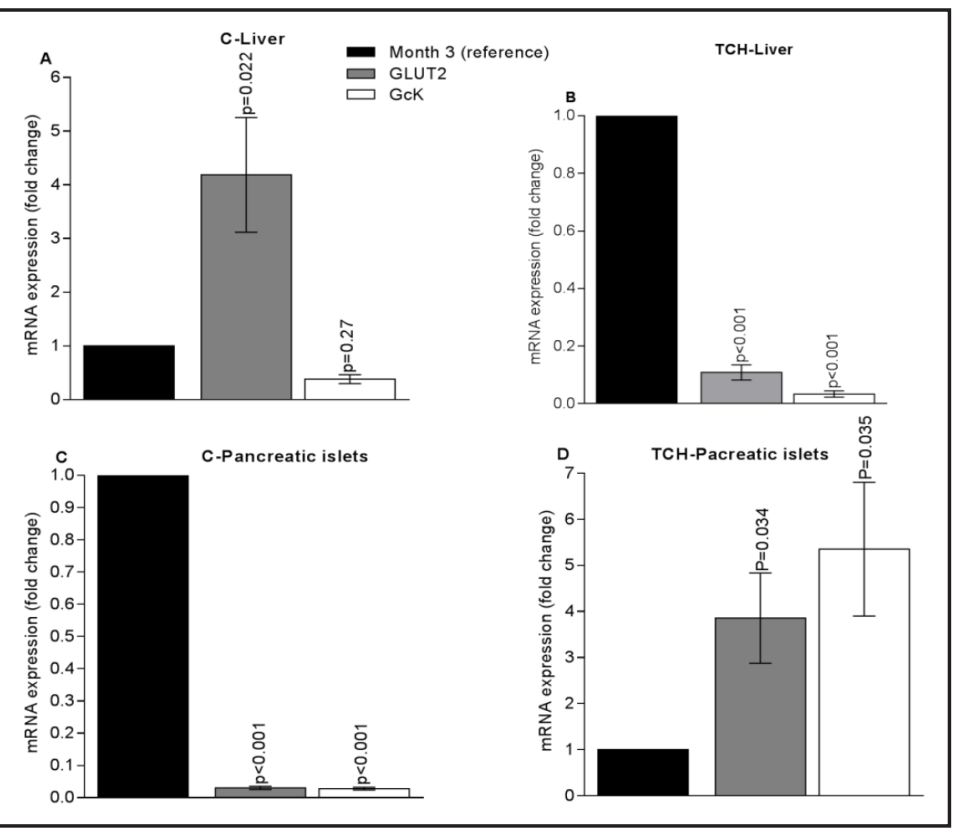
mean \pm SEM; ( $n=6$ rats/group in duplicate). Statistical analysis was performed using the Mann-Whitney U test, $\mathrm{P}<0.05$. GLUT, glucose transporter; GcK, glucokinase; C, control; TCH, transient congenital hypothyroidism.

In this study, the administration of PTU during pregnancy resulted in hypothyroidism in newborn offspring, indicated by the lower levels of circulating $\mathrm{TT}_{3}$ and $\mathrm{TT}_{4}$ and, by the higher levels of TSH. We used a transient model of TCH, as serum concentrations of thyroid hormones and TSH were similar to controls in adult offspring, findings similar to our previous studies $[10,46]$ and others $[27,47]$. Using anti-thyroid drugs for creating animal model of TCH is reasonable and a relatively common practice since $\sim 1-5 \%$ of neonates whose hyperthyroid mothers had been treated with PTU, were born with suppressed thyroid hormones [7, 48-50]. 


\section{Cellular Physiology Cell Physiol Biochem 2017;43:2338-2352 \\ \begin{tabular}{ll|l} 
and Biochemistry & $\begin{array}{l}\text { DOI: 10.1159/000484386 } \\
\text { Published online: October 27, } 2017\end{array}$ & $\begin{array}{l}\text { C } 2017 \text { The Author(s). Published by S. Karger AG, Basel } \\
\text { www.karger.com/cpb }\end{array}$ \\
\hline
\end{tabular}}

In our study, TCH rats had lower weight both at birth and until month 3 , similar to previous reports $[10,11]$. Weight gain was, however, similar between groups during months 3 to 19; a finding in keeping with our previous reports on TCH rats followed until month 12 $[10,44]$.

In the current study, aging was associated with lower expression of GLUT4 in the tissues studied; similarly Mooradian et al., reported lower protein expression of heart GLUT4 in 25 month old vs. 4 month old male rats [32] and Lin et al. reported lower mRNA and protein expression of GLUT4 in epididymal adipose tissue of 20-month old vs. 7-week old male Wistar rats [21]. Decreased protein levels of GLUT4 have been reported in skeletal muscle of aged rats [19, 21, 51] and humans [30]. With aging, lower expression of GLUT4 is associated with both insulin resistance [30,32,51] and impaired glucose tolerance [21]; comparably, in our study, HOMA1-IR was significantly higher in aged euthyroid rats than in young ones $(24.3 \pm 5.0$ vs. $5.1 \pm 0.8, p=0.017)$. In addition, we observed an impaired glucose tolerance in euthyroid aged rats as compared with young ones.

Unlike our results, increased protein expression of GLUT4 is reported in both cardiac and skeletal muscles (soleus muscle) of 25 month vs. 5 month old female C57BL/6 mice [33], in addition, the authors acknowledging these findings differ between mice and rats, indicating a species related difference $[33,52]$. Moreover, it has been reported that aging does not affect GLUT4 protein concentration in the epitrochlearis muscle in female rats (25 vs. 10 month old) [31]; however, it has been suggested that the epitrochlearis muscle unlike the soleus muscle is not suitable for studying age-associated changes in metabolism [51].

In the present study, aging was associated with lower mRNA expression of GLUT1 in all insulin-sensitive tissues; contrary to our results, no changes in GLUT1 protein levels in skeletal muscle $[19,21,22]$, heart muscle [53] or adipose tissue [21, 22] have been observed in aged rats, a difference that we could not explain from the results obtained in our study. It has been reported though that mRNA can change up to 30 -fold with no change in protein levels [54].

Both young and aged offspring rats with TCH observed in this study had higher expression of mRNA for GLUT4 in the heart and soleus muscles and lower expression in the epididymal adipose tissue, results that are consistent with previous studies for heart [32] and adipose tissue [55] in adult hypothyroid rats. Contrary to our results, decreased GLUT4 expression in skeletal and heart muscles[25, 56, 57] and increased GLUT4 expression in adipose tissue [25] have been reported in adult hypothyroid rats; neither are our results in agreement with previous reports in TCH rats, for skeletal and heart muscle on day 4 after birth [26] and in adipose tissue and heart muscle on day 21 after birth [25]. Additionally, no change has been reported in expression of GLUT4 in skeletal and heart muscles in rats with $\mathrm{CH}$ at month 3 after birth [27] or in skeletal and adipose tissue of young adults born with IUGR [58].

Our study shows that TCH in both young and aged rats is associated with lower mRNA expression of GLUT1 in all insulin-sensitive tissues, results in line with previous studies in adipocytes of adult hypothyroid rats [55] and in the skeletal muscle of 4 day old TCH rats [26]. Contrary to our results, higher GLUT1 mRNA expression in the heart $[32,56]$ and adipose tissue [25] of adult hypothyroid rats have been reported; in addition, in rats with TCH, higher GLUT1 mRNA expressions have been reported in the heart muscle at days 4 and 21 [25], and in the adipose tissue at day 4 [26] after birth.

Ghanbari et al. have shown that offspring rats with TCH had lower serum $\mathrm{TT}_{4}$ and $\mathrm{TT}_{3}$ until days 14 and 21 after birth, respectively, despite their thyroid hormone levels being comparable to normal rats 90 days after birth [59]. Mooradian et al. have reported that thyroid hormones have different effects on GLUTs expression during development and in adulthood [32]. Furthermore, thyroid hormones have species-specific and tissue-specific effects on GLUT1 and GLUT4 expression in insulin sensitive tissues $[25,32,60]$. During fetal life, GLUT1 is predominant in insulin sensitive tissues and transition of this dominancy to GLUT4 after birth is regulated by thyroid hormones $[25,26]$. Therefore based on these results, it can be concluded that thyroid hormone deficiency during fetal life impairs normal transition of both GLUT1 and GLUT4 from fetal to adult levels in insulin sensitive tissues 


\section{Cellular Physiology Cell Physiol Biochem 2017;43:2338-2352 \\ \begin{tabular}{ll|l} 
and Biochemistry & $\begin{array}{l}\text { DOI: 10.1159/000484386 } \\
\text { Published online: October 27, } 2017\end{array}$ & $\begin{array}{l}\text { C } 2017 \text { The Author(s). Published by S. Karger AG, Basel } \\
\text { www.karger.com/cpb }\end{array}$ \\
\hline
\end{tabular}}

and can cause insulin resistance [25]. Jaquet et al. have shown that insulin resistance in IUGR-born subjects is associated with impaired expression of GLUT4 in adipose and muscle tissues [58].

In our study, in normal rats, aging was associated with decreased GcK expression in both liver and islets and GLUT2 expression in islets as well as increased GLUT2 expression in the liver. The effects of aging on GcK and GLUT2 expression in animal studies are controversial. In line with our results, lower GcK mRNA expression in the liver of aged rats ( 80 weeks) has been reported [61]. No change in GcK expression in islets has however been reported in 24 month old Fisher rats [62], 80 week old rats [61] or 42 week old rats [63]. Increased mRNA expression of GcK in islets has also been reported in 30 month old mice [64].

In addition, it has been reported that aging is associated with lower GLUT2 mRNA expression in pancreatic islets of 30 month old mice [64], 24-month old mice and rats [65], 7.5 year old rhesus monkeys [66], and 28-month old rats [67]. Contradictory to our results, it has been reported that mRNA and protein expression of GLUT2 decreased in the liver of 20-month-old rats [21]. It has been reported that islet GLUT2 mRNA expression is higher in 6 and 12 month old rats but remained constant in 24-month-old ones [62]. In addition, no change in islet GLUT2 expression has been reported in 42-week-old rats [63].

The likely explanation for the difference between our results and other reports may be related to animal models used, animal age, animal species, the circulating thyroid hormone levels at time of the experiment, and changes in serum insulin levels with age. In addition, expression patterns of genes involving glucose sensing have circadian rhythm [63].

In this study, young TCH rats had lower expression of GLUT2 and GcK in islets, and higher expression of GLUT2 and GcK in liver. To the best of our knowledge, no previous study addressed the effects of TCH on the expression of GLUT2 and GcK in these tissues. It has been shown that male adult hypothyroid rats have lower expression of GLUT2 and GcK in pancreatic islets [28] and liver [29, 68, 69]. It has also been reported that adult hypothyroidism had no effect on GLUT2 and GcK expression in both islets and liver [70, 71]. In this study, we used a transient model of $\mathrm{CH}$, where thyroid hormone levels were similar to normal rats, whereas adult hypothyroid rats usually have lower than normal levels of thyroid hormones [59].

The reverse pattern of GcK and GLUT2 expression in islets and liver observed in our study may be related to differences between promoters of these genes in liver and islets; the liver-specific promoter is regulated by insulin, whereas the islet-specific promoter is regulated by glucose [72-76]. It has been reported that TCH had no effect on the insulin content of islets [2]; low serum insulin in our study may be therefore due to changes in insulin secretion. Data show that low insulin increases GLUT2 mRNA expression in liver [77] ; in addition, liver GLUT2 expression in diabetic rats is higher, findings supporting the idea that hyperglycemia has a positive role in expression of GLUT2 [78]. To sum up, our findings showed that thyroid hormone deficiency during fetal life impairs glucose sensing apparatus in pancreatic islets and liver of offspring rats during adulthood, changes which may all be involved in impaired insulin sensitivity observed in our study.

Our findings showed that in aged TCH rats, GcK and GLUT2 expression were higher in islets and lower in liver. These effects may (at least in part) be due to higher concentrations of circulating glucose levels in the aged $(8.49 \pm 0.26 \mathrm{mmol} / \mathrm{L})$ as compared with young $(6.81$ $\pm 0.67 \mathrm{mmol} / \mathrm{L}$ ) animals, since it has been reported that elevated glucose stimulates GcK and GLUT2 gene expression in islets [79]. In line with our results, expression of GcK has been indeed reported to be lower in the liver of diabetic rats [80] and human [81] as well as higher in islets of diabetic rats [82]. Lower liver GcK mRNA expression could decrease the effects of insulin on the liver and glucose utilization [61], which may be involved in increasing agedependent susceptibility to insulin resistance and diabetes [61]. Higher islet expression of GcK and GLUT2 may be a potential mechanism by which $\beta$-cells attempt to overcome agerelated glucose intolerance and insulin resistance [83]. 


\section{Cellular Physiology Cell Physiol Biochem 2017;43:2338-2352 and Biochemistry POI: 10.1159/000484386 27, 2017 l $\begin{aligned} & \text { (c) } 2017 \text { The Author(s). Published by S. Karger AG, Basel } \\ & \text { www.karger.com/cpb }\end{aligned}$

\section{Conclusion}

Our study shows that thyroid hormone deficiency during fetal life impairs glucose sensing apparatus and changes glucose transporter expression of both young and aged offspring; the effects of TCH on GLUT1, GLUT2, GLUT4, and GcK mRNA expression are age-specific and that TCH intensified decreased GLUT1 mRNA expression in insulin-sensitive tissues in aged rats. The same pattern was observed for GLUT4 mRNA expression in adipose tissue. In the heart and soleus muscles, the aging and TCH had reverse effects on GLUT4 mRNA expression with aging decreasing and TCH increasing the GLUT4 mRNA expression. Finally, our study found that altered expression of glucose transporters and impaired glucose sensing are therefore possibly involved in impaired carbohydrate metabolism in rats with TCH.

\section{Acknowledgements}

This manuscript has been extracted from the thesis written by Hanieh Gholami, MSc student, Department of Genetics, Tehran Medical Branch, Islamic Azad University. This research was funded and supported by the Research Institute for Endocrine Sciences (grant No. 777), Shahid Beheshti University of Medical Sciences, Tehran, Iran.

\section{Disclosure Statement}

The authors declare that they have no conflict of interest with the contents of this article.

\section{References}

$>1$ Liu J, Chen XX, Li XW, Fu W, Zhang WQ: Metabolomic Research on Newborn Infants With Intrauterine Growth Restriction. Medicine (Baltimore) 2016;95:e3564.

-2 Karbalaei N, Ghasemi A, Hedayati M, Godini A, Zahediasl S: The possible mechanisms by which maternal hypothyroidism impairs insulin secretion in adult male offspring in rats. Exp Physiol 2014;99:701-714.

-3 Sedaghat K, Zahediasl S, Ghasemi A: Intrauterine programming. Iran J Basic Med Sci 2015;18:212-220.

-4 Springer D, Jiskra J, Limanova Z, Zima T, Potlukova E: Thyroid in pregnancy: From physiology to screening. Crit Rev Clin Lab Sci 2017;54:102-116.DOI: 10.1080/10408363.2016.1269309

-5 Miller LD, McPhie P, Suzuki H, Kato Y, Liu ET, Cheng SY: Multi-tissue gene-expression analysis in a mouse model of thyroid hormone resistance. Genome Biol 2004;5:R31.

6 Rastogi MV, LaFranchi SH: Congenital hypothyroidism. Orphanet J Rare Dis 2010;5:17.

7 Ghanbari M, Ghasemi A: Maternal hypothyroidism: An overview of current experimental models. Life Sci 2017. DOI: $10.1016 /$ j.lfs.2017.08.012

8 Ahmad N, Irfan A, Al Saedi SA: Congenital hypothyroidism: Screening, diagnosis, management, and outcome. J Clin Neonatology 2017;6:64-70. DOI: 10.4103/jcn.JCN_5_17

9 Delange F: Screening for congenital hypothyroidism used as an indicator of the degree of iodine deficiency and of its control. Thyroid 1998;8:1185-1192.

10 Karbalaei N, Ghasemi A, Faraji F, Zahediasl S: Comparison of the effect of maternal hypothyroidism on carbohydrate metabolism in young and aged male offspring in rats. Scand J Clin Lab Invest 2013;73:87-94.

-11 Farahani H, Ghasemi A, Roghani M, Zahediasl S: The effect of maternal hypothyroidism on the carbohydrate metabolism and insulin secretion of isolated islets in adult male offspring of rats. Horm Metab Res 2010;42:792-797.

12 Fowden AL, Giussani DA, Forhead AJ: Intrauterine programming of physiological systems: causes and consequences. Physiology (Bethesda) 2006;21:29-37.

13 Bourguignon JP, Parent AS: Early homeostatic disturbances of human growth and maturation by endocrine disrupters. Curr Opin Pediatr 2010;22:470-477.

14 Kirkman MS, Briscoe VJ, Clark N, Florez H, Haas LB, Halter JB, Huang ES, Korytkowski MT, Munshi MN, Odegard PS: Diabetes in older adults. Diabetes care 2012;35:2650-2664.

15 Gong Z, Muzumdar RH: Corrigendum to "Pancreatic Function, Type 2 Diabetes, and Metabolism in Aging". Int J Endocrinol 2017;2017:2131060. 


\section{Cellular Physiology Cell Physiol Biochem 2017;43:2338-2352 \begin{tabular}{l|l|l|l|}
\hline DOI: 101159/000484386 2017 The Author(s). Published by S. Karger AG, Basel & (c)
\end{tabular} and Biochemistry

16 Tang Y, Purkayastha S, Cai D: Hypothalamic microinflammation: a common basis of metabolic syndrome and aging. Trends Neurosci 2015;38:36-44.

17 Lipska KJ, Krumholz H, Soones T, Lee SJ: Polypharmacy in the Aging Patient: A Review of Glycemic Control in Older Adults With Type 2 Diabetes. JAMA 2016;315:1034-1045.

-18 Mooradian AD, Morin AM, Cipp LJ, Haspel HC: Glucose transport is reduced in the blood-brain barrier of aged rats. Brain Res 1991;551:145-149.

19 dos Santos JM, Benite-Ribeiro SA, Queiroz G, Duarte JA: The effect of age on glucose uptake and GLUT1 and GLUT4 expression in rat skeletal muscle. Cell Biochem Funct 2012;30:191-197.

20 Brennand K, Melton D: Slow and steady is the key to beta-cell replication. J Cell Mol Med 2009;13:472-487.

21 Lin J-L, Asano T, Shibasaki Y, Tsukuda K, Katagiri H, Ishihara H, Takaku F, Oka Y: Altered expression of glucose transporter isoforms with aging in rats-selective decrease in GluT4 in the fat tissue and skeletal muscle. Diabetologia 1991;34:477-482.

-22 Oka Y, Asano T, Lin JL, Tsukuda K, Katagiri H, Ishihara H, Inukai K, Yazaki Y: Expression of glucose transporter isoforms with aging. Gerontology 1992;38 Suppl 1:3-9.

-23 Kajantie E, Strang-Karlsson S, Hovi P, Wehkalampi K, Lahti J, Kaseva N, Jarvenpaa AL, Raikkonen K, Eriksson JG, Andersson S: Insulin sensitivity and secretory response in adults born preterm: the Helsinki Study of Very Low Birth Weight Adults. J Clin Endocrinol Metab 2015;100:244-250.

24 Kajantie E, Osmond C, Barker DJ, Eriksson JG: Preterm birth--a risk factor for type 2 diabetes? The Helsinki birth cohort study. Diabetes Care 2010;33:2623-2625.

-25 Castello A, Rodriguez-Manzaneque JC, Camps M, Perez-Castillo A, Testar X, Palacin M, Santos A, Zorzano A: Perinatal hypothyroidism impairs the normal transition of GLUT4 and GLUT1 glucose transporters from fetal to neonatal levels in heart and brown adipose tissue. Evidence for tissue-specific regulation of GLUT4 expression by thyroid hormone. J Biol Chem 1994;269:5905-5912.

-26 Ramos S, Goya L, Alvarez C, Martin MA, Agote M, Escriva F, Pascual-Leone AM: Different role of insulin in GLUT-1 and -4 regulation in heart and skeletal muscle during perinatal hypothyroidism. Am J Physiol Endocrinol Metab 2001;281:E1073-1081.

27 Annapoorna K, Anbalagan J, Neelamohan R, Vengatesh G, Stanley J, Amudha G, Aruldhas MM: Transient gestational and neonatal hypothyroidism-induced specific changes in androgen receptor expression in skeletal and cardiac muscles of adult rat. Horm Metab Res 2013;45:197-205.

28 Godini A, Ghasemi A, Zahediasl S: The Possible Mechanisms of the Impaired Insulin Secretion in Hypothyroid Rats. PLoS One 2015;10:e0131198.

-29 Kemp HF, Hundal HS, Taylor PM: Glucose transport correlates with GLUT2 abundance in rat liver during altered thyroid status. Mol Cell Endocrinol 1997;128:97-102.

- 30 Houmard JA, Weidner MD, Dolan PL, Leggett-Frazier N, Gavigan KE, Hickey MS, Tyndall GL, Zheng D, Alshami A, Dohm GL: Skeletal muscle GLUT4 protein concentration and aging in humans. Diabetes 1995;44:555-560.

-31 Gulve EA, Rodnick KJ, Henriksen EJ, Holloszy JO: Effects of wheel running on glucose transporter (GLUT4) concentration in skeletal muscle of young adult and old rats. Mech Ageing Dev 1993;67:187-200.

-32 Mooradian AD, Chehade JM, Kim J: Age-related changes in thyroid hormone effects on glucose transporter isoforms of rat heart. Life Sci 1999;65:981-989.

33 Martineau LC, Chadan SG, Parkhouse WS: Age-associated alterations in cardiac and skeletal muscle glucose transporters, insulin and IGF-1 receptors, and PI3-kinase protein contents in the C57BL/6 mouse. Mech Ageing Dev 1999;106:217-232.

-34 Gong Z, Muzumdar RH: Pancreatic function, type 2 diabetes, and metabolism in aging. Int J Endocrinol 2012;2012:320482.

-35 Fischer Y, Thomas J, Sevilla L, Munoz P, Becker C, Holman G, Kozka IJ, Palacin M, Testar X, Kammermeier $\mathrm{H}$, Zorzano A: Insulin-induced recruitment of glucose transporter 4 (GLUT4) and GLUT1 in isolated rat cardiac myocytes. Evidence of the existence of different intracellular GLUT4 vesicle populations. J Biol Chem 1997;272:7085-7092.

36 Council NR: Guide for the care and use of laboratory animals, 8, National Academies Press2010.

-37 Fitts DA: Ethics and animal numbers: informal analyses, uncertain sample sizes, inefficient replications, and type I errors. J Am Assoc Lab Anim Sci 2011;50:445-453.

38 Charan J, Biswas T: How to calculate sample size for different study designs in medical research? Indian J Psychol Med 2013;35:121-126. 


\section{Cellular Physiology Cell Physiol Biochem 2017;43:2338-2352

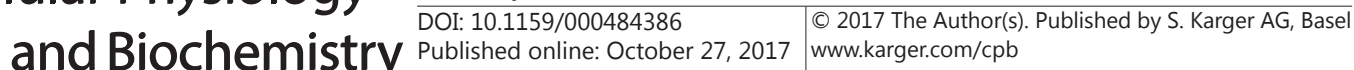

-39 Henning Y, Vole C, Begall S, Bens M, Broecker-Preuss M, Sahm A, Szafranski K, Burda H, Dammann P: Unusual ratio between free thyroxine and free triiodothyronine in a long-lived mole-rat species with bimodal ageing. PLoS One 2014;9:e113698.

40 Christian MS, Trenton NA: Evaluation of thyroid function in neonatal and adult rats: The neglected endocrine mode of action. Pure and applied chemistry 2003;75:2055-2068.

41 Davies DT: Assessment of Rodent Thyroid Endocrinology: Advantages and Pit-Falls*. Comp Haematol In 1993;3:142-152.

-42 Ghasemi A, Tohidi M, Derakhshan A, Hasheminia M, Azizi F, Hadaegh F: Cut-off points of homeostasis model assessment of insulin resistance, beta-cell function, and fasting serum insulin to identify future type 2 diabetes: Tehran Lipid and Glucose Study. Acta Diabetol 2015;52:905-915.

43 Lacy PE, Kostianovsky M: Method for the isolation of intact islets of Langerhans from the rat pancreas. Diabetes 1967;16:35-39.

44 Jeddi S, Zaman J, Ghasemi A: Effect of fetal hypothyroidism on tolerance to ischemia-reperfusion injury in aged male rats: Role of nitric oxide. Nitric Oxide 2016;55-56:82-90.

45 Ghasemi A, Zahediasl S: Normality tests for statistical analysis: a guide for non-statisticians. Int J Endocrinol Metab 2012;10:486-489.

46 Ghasemi A, Mehrazin F, Zahediasl S: Effect of nitrate and L-arginine therapy on nitric oxide levels in serum, heart, and aorta of fetal hypothyroid rats. J Physiol Biochem 2013;69:751-759.

-47 Hamouli-Said Z, Tahari F, Hamoudi F, Hadj-Bekkouche F: Comparative study of the effects of pre and post natal administration of a thyroid drug on testicular activity in adult rat. Folia Histochem Cytobiol 2007;45 Suppl 1:S51-57.

-48 Becks GP, Burrow GN: Thyroid disease and pregnancy. Med Clin North Am 1991;75:121-150.

-49 Andersen SL, Olsen J, Wu CS, Laurberg P: Birth defects after early pregnancy use of antithyroid drugs: a Danish nationwide study. J Clin Endocrinol Metab 2013;98:4373-4381.

50 Diav-Citrin 0, Ornoy A: Teratogen update: antithyroid drugs-methimazole, carbimazole, and propylthiouracil. Teratology 2002;65:38-44.

51 Larkin LM, Reynolds TH, Supiano MA, Kahn BB, Halter JB: Effect of aging and obesity on insulin responsiveness and glut-4 glucose transporter content in skeletal muscle of Fischer 344 x Brown Norway rats. J Gerontol A Biol Sci Med Sci 2001;56:B486-492.

52 Carter TA, Greenhall JA, Yoshida S, Fuchs S, Helton R, Swaroop A, Lockhart DJ, Barlow C: Mechanisms of aging in senescence-accelerated mice. Genome Biol 2005;6:R48.

53 Mooradian AD, Wong NC: Age-related changes in thyroid hormone action. Eur J Endocrinol 1994;131:451461.

54 Gygi SP, Rochon Y, Franza BR, Aebersold R: Correlation between protein and mRNA abundance in yeast. Mol Cell Biol 1999;19:1720-1730.

55 Matthaei S, Trost B, Hamann A, Kausch C, Benecke H, Greten H, Hoppner W, Klein HH: Effect of in vivo thyroid hormone status on insulin signalling and GLUT1 and GLUT4 glucose transport systems in rat adipocytes. J Endocrinol 1995;144:347-357.

56 Weinstein SP, Haber RS: Differential regulation of glucose transporter isoforms by thyroid hormone in rat heart. Biochim Biophys Acta 1992;1136:302-308.

57 Weinstein SP, Watts J, Haber RS: Thyroid hormone increases muscle/fat glucose transporter gene expression in rat skeletal muscle. Endocrinology 1991;129:455-464.

-58 Jaquet D, Vidal H, Hankard R, Czernichow P, Levy-Marchal C: Impaired regulation of glucose transporter 4 gene expression in insulin resistance associated with in utero undernutrition. J Clin Endocrinol Metab 2001;86:3266-3271.

-59 Ghanbari M, Bagheripuor F, Piryaei A, Zahediasl S, Noroozzadeh M, Ghasemi A: Hemodynamic properties and arterial structure in male rat offspring with fetal hypothyroidism. Gen Physiol Biophys 2016;35:397405.

60 Hocquette JF, Sauerwein H, Higashiyama Y, Picard B, Abe H: Prenatal developmental changes in glucose transporters, intermediary metabolism and hormonal receptors related to the IGF/insulin-glucose axis in the heart and adipose tissue of bovines. Reprod Nutr Dev 2006;46:257-272.

-61 Jiang MH, Fei J, Lan MS, Lu ZP, Liu M, Fan WW, Gao X, Lu DR: Hypermethylation of hepatic Gck promoter in ageing rats contributes to diabetogenic potential. Diabetologia 2008;51:1525-1533. 


\section{Cellular Physiology Cell Physiol Biochem 2017;43:2338-2352

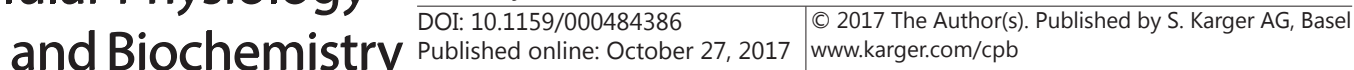

62 Giddings SJ, Carnaghi LR, Mooradian AD: Age-related changes in pancreatic islet cell gene expression. Metabolism 1995;44:320-324.

-63 Frese T, Bazwinsky I, Muhlbauer E, Peschke E: Circadian and age-dependent expression patterns of GLUT2 and glucokinase in the pancreatic beta-cell of diabetic and nondiabetic rats. Horm Metab Res 2007;39:567574.

64 Perfetti R, Wang Y, Shuldiner AR, Egan JM: Molecular investigation of age-related changes in mouse endocrine pancreas. J Gerontol A Biol Sci Med Sci 1996;51:B331-336.

-65 Ihm SH, Moon HJ, Kang JG, Park CY, Oh KW, Jeong IK, Oh YS, Park SW: Effect of aging on insulin secretory function and expression of beta cell function-related genes of islets. Diabetes Res Clin Pract 2007;77 Suppl 1:S150-154.

66 Kramer J, Moeller EL, Hachey A, Mansfield KG, Wachtman LM: Differential expression of GLUT2 in pancreatic islets and kidneys of New and Old World nonhuman primates. Am J Physiol Regul Integr Comp Physiol 2009;296:R786-793.

67 Novelli M, De Tata V, Bombara M, Bergamini E, Masiello P: Age-dependent reduction in GLUT-2 levels is correlated with the impairment of the insulin secretory response in isolated islets of Sprague-Dawley rats. Exp Gerontol 2000;35:641-651.

68 Weinstein SP, O’Boyle E, Fisher M, Haber RS: Regulation of GLUT2 glucose transporter expression in liver by thyroid hormone: evidence for hormonal regulation of the hepatic glucose transport system. Endocrinology 1994;135:649-654.

69 Hoppner W, Seitz HJ: Effect of thyroid hormones on glucokinase gene transcription in rat liver. J Biol Chem 1989;264:20643-20647.

$\rightarrow 0$ Mokuno T, Uchimura K, Hayashi R, Hayakawa N, Makino M, Nagata M, Kakizawa H, Sawai Y, Kotake M, Oda N, Nakai A, Nagasaka A, Itoh M: Glucose transporter 2 concentrations in hyper- and hypothyroid rat livers. J Endocrinol 1999;160:285-289.

71 Taguchi Y, Tasaki Y, Terakado K, Kobayashi K, Machida T, Kobayashi T: Impaired insulin secretion from the pancreatic islets of hypothyroidal growth-retarded mice. J Endocrinol 2010;206:195-204.

72 Baltrusch S, Tiedge M: Glucokinase regulatory network in pancreatic $\beta$-cells and liver. Diabetes 2006;55:S55-S64.

73 Iynedjian PB, Pilot PR, Nouspikel T, Milburn JL, Quaade C, Hughes S, Ucla C, Newgard CB: Differential expression and regulation of the glucokinase gene in liver and islets of Langerhans. Proc Natl Acad Sci U S A 1989;86:7838-7842.

74 Kim JW, Kim YK, Ahn YH: A mechanism of differential expression of GLUT2 in hepatocyte and pancreatic beta-cell line. Exp Mol Med 1998;30:15-20.

75 Massa ML, Gagliardino JJ, Francini F: Liver glucokinase: An overview on the regulatory mechanisms of its activity. IUBMB Life 2011;63:1-6.

-76 Bedoya FJ, Matschinsky FM, Shimizu T, O’Neil JJ, Appel MC: Differential regulation of glucokinase activity in pancreatic islets and liver of the rat. J Biol Chem 1986;261:10760-10764.

-77 Bae JS, Kim TH, Kim MY, Park JM, Ahn YH: Transcriptional regulation of glucose sensors in pancreatic betacells and liver: an update. Sensors (Basel) 2010;10:5031-5053.

78 Marks J, Carvou NJ, Debnam ES, Srai SK, Unwin RJ: Diabetes increases facilitative glucose uptake and GLUT2 expression at the rat proximal tubule brush border membrane. J Physiol 2003;553:137-145.

79 Tiedge M, Lenzen S: Effects of glucose refeeding and glibenclamide treatment on glucokinase and GLUT2 gene expression in pancreatic B-cells and liver from rats. Biochem J 1995;308:139-144.

-80 Iynedjian PB, Gjinovci A, Renold AE: Stimulation by insulin of glucokinase gene transcription in liver of diabetic rats. J Biol Chem 1988;263:740-744.

81 Haeusler RA, Camastra S, Astiarraga B, Nannipieri M, Anselmino M, Ferrannini E: Decreased expression of hepatic glucokinase in type 2 diabetes. Mol Metab 2015;4:222-226.

82 Burcelin R, Eddouks M, Kande J, Assan R, Girard J: Evidence that GLUT-2 mRNA and protein concentrations are decreased by hyperinsulinaemia and increased by hyperglycaemia in liver of diabetic rats. Biochem J 1992;288:675-679.

83 Gunasekaran U, Gannon M: Type 2 diabetes and the aging pancreatic beta cell. Aging (Albany NY) 2011;3:565-575. 